\title{
SINTESIS BAHAN PIEZOELEKTRIK XBZT-BCT MENGGUNAKAN METODE MOLTEN SALT DAN KARAKTERISASINYA
}

\author{
Helga Dwi Fahyuan ${ }^{1^{*}}$, Oky Lidya Kumala ${ }^{1}$, Nasri $\mathrm{Mz}^{2}$ \\ ${ }^{I}$ Program Studi Fisika, FST, Universitas Jambi, \\ Jl. Raya Jambi - Muara Bulian KM 15 \\ Mandalo Darat, Jambi, 36361, Indonesia \\ ${ }^{2}$ Program Studi Teknik Geofisika, \\ Jurusan Teknik Kebumian, Fakultas Sains dan Teknologi, \\ Universitas Jambi, Jalan Lintas Jambi-Muara Bulian KM 15, \\ Mendalo Darat, Jambi Luar Kota, Kota Jambi, 36122, Indonesia \\ *Email : helgadwifahyuan@unja.ac.id
}

\begin{abstract}
The research of synthesized XBZT-BCT piezoelectric material have been carried out by using molten salt method. Piezoelectric material is a material that can generate electrical voltage when given voltage or mechanical strain. This material has the potential to be a good piezoelectric material. In this study, the method used is molten salt. Molten salt utilizes molten salt to speed up chemical reactions during the heating process. The XBZT-BCT material was synthesized with variations of composition $0.48,0.5$, and $0.52 \mathrm{~mol}$ and sintering temperature is $850^{\circ} \mathrm{C}$. The crystalline structure generated by $0.48 B Z T-B C T$ sintering temperature of $850^{\circ} \mathrm{C}$ is tetragonal-rhombohedral., respectively. The Morphotropic Phase Boundary area is present in a composition of $0.5 \mathrm{~mol}$.
\end{abstract}

Keywords: piezoelectric; molten salt method; morphotropic phase boundary.

\begin{abstract}
ABSTRAK
Telah dilakukan sintesis material piezoelektrik xBZT-BCT menggunakan metode molten salt. Material piezoelektrik adalah material yang dapat menghasilkan tegangan listrik apabila diberi tegangan maupun regangan mekanik. Material ini berpotensi untuk menjadi material piezoelektrik yang baik. Pada penelitian ini, metode yang digunakan adalah molten salt. Molten salt memanfaatkan lelehan garam untuk mempercepat reaksi kimia selama proses pemanasan. Material XBZT-BCT disintesis dengan variasi komposisi 0,48, 0,5, dan $0,52 \mathrm{~mol}$ semenggunakan suhu sintering $850^{\circ} \mathrm{C}$. Struktur ristal yang dihasilkan oleh 0,48BZT-BCT suhu sintering $850^{\circ} \mathrm{C}$ adalah tetragonal-rhombohedral. Daerah Morphotropic Phase Boundary-nya terdapat di komposisi $0,5 \mathrm{~mol}$.
\end{abstract}

Kata kunci: piezoelektrik; metode molten salt; morphotropic phase boundary.

\section{PENDAHULUAN}

Pengembangan teknologi saat ini sudah sangat maju, terutama di bidang teknologi penghasil energi listrik. Teknologi penghasil energi listrik ini menggunakan material tertentu dan bisa dibuat dalam skala industri. Salah satunya adalah material piezoelektrik. Menurut Yulianti, et. al (2010) [1], material piezoelektrik adalah suatu material yang memiliki kemampuan untuk menghasilkan tegangan listrik jika diberi tekanan atau regangan.

Material piezoelektrik yang digunakan pada awalnya adalah $\mathrm{PbZr}_{\mathrm{x}} \mathrm{Ti}_{1-\mathrm{x}} \mathrm{O}_{3}$ atau biasa disingkat PZT. Penggunaan timbal pada PZT mencapai $60 \%$ wt [2]. Karena itu, material PZT berbahaya bagi tubuh maupun lingkungan apabila diproduksi dalam skala industry [1]. Material piezoelektrik yang tidak menggunakan $\mathrm{Pb}$ semakin banyak seperti $\mathrm{K}_{\mathrm{x}} \mathrm{Na}_{1-\mathrm{x}} \mathrm{NbO}_{3}$ (KNN), $\mathrm{Bi}_{\mathrm{x}} \mathrm{Na}_{1-\mathrm{x}} \mathrm{TiO}_{3}$ (BNT), $\mathrm{BaZr}_{\mathrm{x}} \mathrm{Ti}_{1-\mathrm{x}} \mathrm{O}_{3}$ (BZT), dan lain-lain. Material BZT memiliki struktur perovskitetetragonaldan dianggap menjadi kandidat yang baik sebagai pengganti material piezoelektrik non-PZT. Hal ini dikarenakan BZT memiliki polarisasi remanen yang besar $(P r=13-18$ $\left.\mu \mathrm{C} / \mathrm{cm}^{2}\right)$, medan koersif yang kecil $(E c=0,08$ $0,35 \mathrm{kV} / \mathrm{mm}$ ), dan koefisian piezoelektrik yang 
tinggi $\left(d_{33}=236 \mathrm{pC} / \mathrm{N}\right)$, dan $\mathrm{Tc}$ yang rendah sekitar $100^{\circ} \mathrm{C}$ [3]. Meskipun demikian, BZT belum mampu menyaingi PZT yang memiliki nilai $d_{33}=460 \mathrm{pC} / \mathrm{N}, K p=0.56, P r=39,2$ $\mu \mathrm{C} / \mathrm{cm}^{2}, E c=14,9 \mathrm{kV} / \mathrm{cm}$, dan $T c=450{ }^{\circ} \mathrm{C}$ [4]. Karena itu, untuk meningkatkan performance dari BZT maka diperlukan pendopingan dengan $\mathrm{Ba}_{x} \mathrm{Ca}_{1-\mathrm{x}} \mathrm{TiO}_{3}$ (BCT). Penelitian ini bertujuan untuk mengidentifikasi pengaruh variasi komposisi mol dan suhu sintering terhadap karakteristik dari bahan piezoelektrik xBZT-BCT.

Pada penelitian ini, metode yang digunakan untuk mensintesis bahan piezoelektrik xBZT-(1-x)BCT adalah molten salt. Metode ini memanfaatkan garam $\mathrm{NaCl}$ dan $\mathrm{KCl}$ sebagai katalisator proses kimia yang terjadi pada saat proses sintering berlangsung. Hal ini juga dikarenakan garam yang digunakan pada metode ini tidak ikut bereaksi terhadap sampel sehingga tidak terjadi perubahan senyawa. Penggunaan molten salt ini dikarenakan metode ini dapat menghasilkan material piezoelektrik yang baik, pengerjaannya cukup sederhana, dan menggunakan suhu kalsinasi dan sintering yang rendah.

\section{METODE}

Bahan yang digunakan pada percobaan ini adalah $\mathrm{BaCO}_{3}$ Merck 99\% (Pro Analyst), $\mathrm{ZrOCl}_{2} .8 \mathrm{H}_{2} \mathrm{O}$ Merck 99\% (Pro Analyst), $\mathrm{TiO}_{2}$ Merck $99 \%$ (Pro Analyst), $\mathrm{CaCO}_{3}$ Merck 99\% (Pro Analyst), NaCl Merck 99\% (Pro Analyst), $\mathrm{KCl}$ Merck 99\% (Pro Analyst), aquades, kertas saring, kertas perkamen, plastik klip, dan $\mathrm{AgNO}_{3}$ Merck 99\%.

Persamaan reaksi kimia yang digunakan untuk sintesis xBZT-BCT adalah:

$$
\begin{aligned}
& \mathrm{BaZr}_{0,2} \mathrm{Ti}_{0,8} \mathrm{O}_{3}+(1-\mathrm{x}) \quad \mathrm{Ba}_{0,7} \mathrm{Ca}_{0,3} \mathrm{TiO}_{3} \\
& \mathrm{xBaZr}_{0,2} \mathrm{Ti}_{0,8} \mathrm{O}_{3}-(1-\mathrm{x}) \mathrm{Ba}_{0,7} \mathrm{Ca}_{0,3} \mathrm{TiO}_{3}
\end{aligned}
$$

Variasi komposisi mol yang digunakan adalah 0,48, 0,5, dan 0,52. Massa prekursor ditimbang dan digerus selama 4 jam. Massa BZT-BCT dan garam yang telah digerus tersebut ditimbang dan massanya harus sama. Kemudian, keduanya digabungkan dan digerus selama 3 jam. Penggerusan ini dilakukan untuk membuat ukuran partikelnya lebih kecil dan homogen. Sampel BZT-BCT dikalsinasi dengan suhu $250^{\circ} \mathrm{C}$ selama 2,5 jam. Kalsinasi bertujuan untuk menghilangkan pengotor organik yang masuk saat penggerusan maupun transportasi bahan. Setelah dikalsinasi, sampel disintering dengan suhu $950^{\circ} \mathrm{C}$. Waktu yang digunakan untuk sintering masing-masing suhu adalah 4 jam. Proses sintering dilakukan agar proses kimia terjadi di dalam lelehan garam.

Produk hasil sintering masih memiliki kandungan garam di dalamnya maka perlu dilakukan pemisahan dengan cara dicuci sebanyak 15-20 kali. Sampel ditetesi larutan $\mathrm{AgNO}_{3}$ untuk menguji adanya garam di dalam sampel. Produk hasil pemisahan garam kemudian dikeringkan menggunakan oven selama 2 jam dengan suhu $110^{\circ} \mathrm{C}$. Kemudian, sampel dipanaskan kembali dengan suhu yang sama selama 30 menit. Massa sampel ditimbang kemudian sampel dipanaskan kembali dengan suhu $110^{\circ} \mathrm{C}$ selama 30 menit. Massa sampel kemudian ditimbang kembali. Apabila massa kedua pengeringan tersebut sama maka kandungan air di dalam sampel sudah hilang. Apabila massanya beda maka sampel dipanaskan kembali. Produk hasil sintesis perlu dilakukan karakterisasi menggunakan XRD untuk melihat struktur kristal dan ukuran Kristal, serta dilanjutkan dengan analisis refinement dengan software high scor plus.

\section{HASIL DAN PEMBAHASAN}

Pada Gambar 1, menunjukan hasil sintesis BZT-BCT dengan variasi komposisi mol dan suhu sintering. Puncak-puncak difraksi yang dihasilkan hampir sama untuk semua variasi mol dan suhu sinteringnya. 


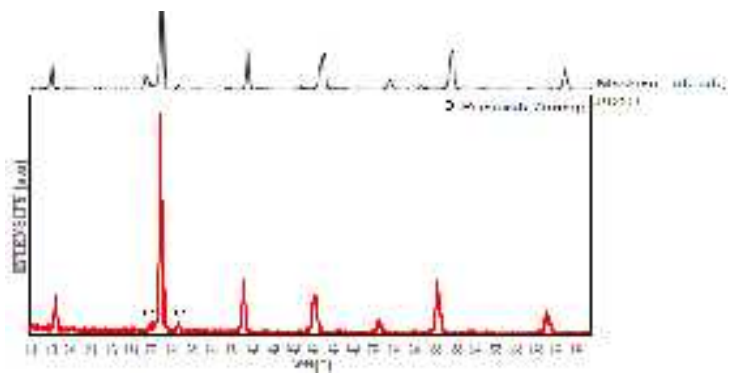

(a)

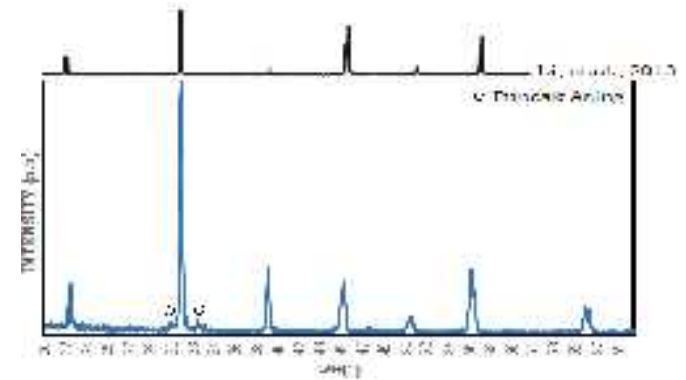

(b)

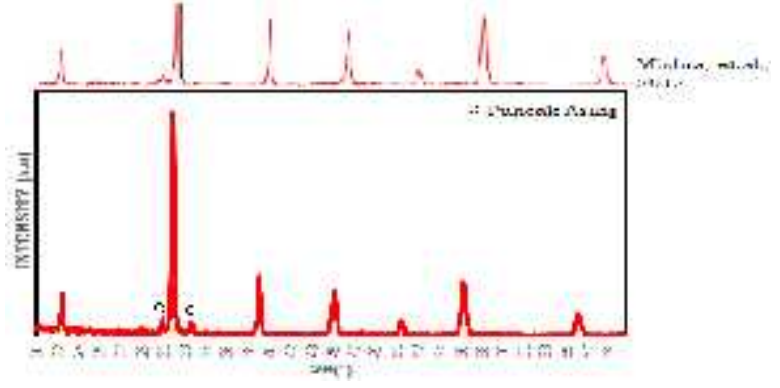

(c)

Gambar 1. Hasil Sintesis Bahan Piezoelektrik BZT-BCT dengan variasi mol dan suhu sintering: (a) 0,48 mol; (b) 0,5 mol; dan (c) $0,52 \mathrm{~mol}$.

Hasil sintesis 0,48BZT-BCT ditunjukan pada Gambar 1 (a). Puncak dari hasil karakterisasi ini dicocokan dengan hasil karakterisasi 0,48BZT-BCT oleh Mishra, et. al. (2012) [5]. Puncak keduanya berada di posisi $2 \theta$ yang sama. Namun, pada puncak hasil sintesis 0,48 BZT-BCT tidak muncul puncak asing pada posisi $30,7^{\circ}$ dan $33,13^{\circ}$ tersebut mulai terbentuk pada sintesis menggunakan metode molten salt. Secara kualitatif, hasil sintesis $0,48 \mathrm{BZT}$-BCT berhasil degan metode molten salt.

Gambar 1 (b) menunjukan hasil karakterisasi 0,5BZT-BCT terdapat puncak asing di posisi $2 \theta 30,73^{\circ}$ dan $33,35^{\circ}$. Secara keseluruhan, pada material 0,5BZT-BCT dari suhu sintering $950^{\circ} \mathrm{C}$ sudah memiliki struktur perovskite di mana belum terbentuk secara sempurna (dalam tahap pembentukan struktur perovskite) akibat adanya puncak-puncak asing yang berada di pola difraksi tersebut. Hal ini lah yang menjadi cikal bakal adanya fasa transisi dari tetragonal menuju rhombohedral (MPB).

Bahan piezoelektrik BZT-BCT yang ditunjukan pada Gambar 1 (c) yang divariasikan dengan komposisi 0,52 menunjukan kesamaan dengan puncak dari hasil penelitian yang dilakukan oleh Mishra, et.al. (2012). Puncak asing dari hasil karakterisasi juga terbentuk pada variasi komposisi mol ini, walaupun suhu sintering yang digunakan lebih rendah sebesar $950^{\circ} \mathrm{C}$ dari pada suhu sintering yang digunakan oleh Mishra et.al., yaitu sebesar $1100^{\circ} \mathrm{C} .950^{\circ} \mathrm{C}$ puncaknya berada di posisi $2 \theta$ yang sama dengan pola difraksi dari penelitian Mishra, et.al. (2012). Puncak-puncak asingnya berada di posisi $2 \theta 30,70^{\circ}$ dan $33,32^{\circ}$.

\section{Hasil Refinement xBZT-BCT}

Bahan piezoelektrik xBZT-BCT yang telah dikarakterisasi dengan XRD perlu dilakukan refinement. Hasilnya ditunjukan pada Gambar 2.

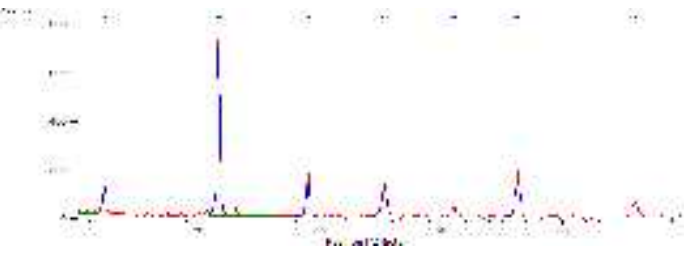

(a)

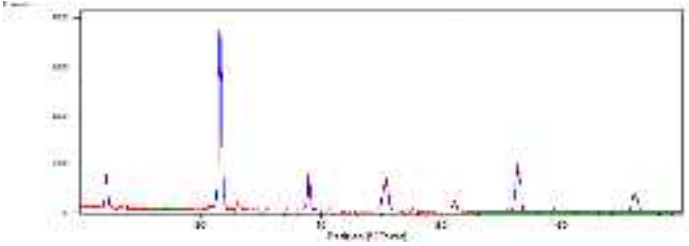

(b)

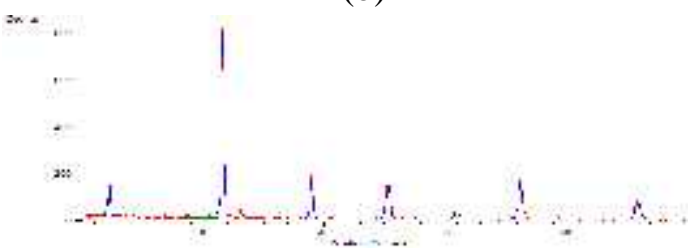

(c)

Gambar 2. Hasil Refinement BZT-BCT dengan suhu sintering $950^{\circ} \mathrm{C}$ untuk variasi komposisi:0,48 mol; (b) 0,5 mol; dan (c) 0,52 mol. 
Pada Gambar 2 (a), 0,48BZT-BCT disintesis dengan suhu sintering $950^{\circ} \mathrm{C}$. Nilai GoF-nya adalah 1,53. Kecocokan antara database dengan hasil refinement adalah ICSD 98-007-2668 ( $\left.\mathrm{BaxCa}(1-\mathrm{x}) \mathrm{TiO}_{3}\right)$. Struktur kristal yang didapat adalah tetragonal dengan unit cell-nya $\mathrm{a}=3,9840 \AA \mathrm{A}, \mathrm{b}=3,9840$ $\AA, c=4,0260 \AA, \alpha=90^{\circ}, \beta=90^{\circ}, \quad=90^{\circ}$. Gambar 2 (b) menunjukan 0,5BZT-BCT yang disintesis dengan suhu $950^{\circ} \mathrm{C}$ menghasilkan nilai GoF sebesar 1,53. Kecocokan dengan database dengan hasil refinement adalah ICSD 98-007-2668 ( $\left.\mathrm{BaxCa}(1-\mathrm{x}) \mathrm{TiO}_{3}\right)$. Unit cell-nya $\mathrm{a}=3,9840 \AA, \mathrm{b}=3,9840 \AA, \mathrm{c}=$ $4,0260 \AA, \alpha=90^{\circ}, \beta=90^{\circ}, \quad=90^{\circ}$. Pada Gambar 2 (c), nilai GoF yang dihasilkan dari refinement pertama adalah 1,61. Hasil refinement pertama menunjukan kecocokan dengan ICSD 98-007-1369 ( $\left.\mathrm{BaxCa}(1-x) \mathrm{TiO}_{3}\right)$. Struktur yang terbentuk dari 0,52BZT-BCT ini adalah tetragonal (Lampiran 14) dengan paramater kisi yang didapat $\mathrm{a}=3,9840 \AA, \mathrm{b}=$ $3,9840 \AA, c=4,0260 \AA, \alpha=90^{\circ}, \beta=90^{\circ}, \quad=$ $90^{\circ}$. Dari ketiga variasi komposisi mol untuk bahan piezoelektrik BZT-BCT, tidak terbentuk dua struktur kristal maupun perubahan dari tetragonal menuju rhombohedral secara kuantitas.

\section{MPB dari xBZT-BCT}

Perubahan struktur dari tetragonal menuju rhombohedral berdasarkan bentuk puncaknya ditunjukan pada Gambar 3.

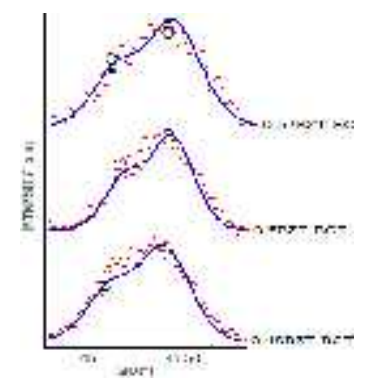

Gambar 3. Pola Difraksi xBZT-BCT pada sudut $31,40^{\circ}-31,80^{\circ}$ dan $45^{\circ}-45,50^{\circ}$ dengan suhu sintering $950^{\circ} \mathrm{C}$

Pada Gambar 3, menunjukan bahwa bidang hkl (110) tidak simetris terhadap bidang (002) dari variasi $0,48 \mathrm{~mol}$ pada material BZT-BCT. Pada pola difraksi penggunaan 0,5 mol BZT, bidang (110) tidak simetris pada bidang (002) sehingga terlihat jelas adanya dua puncak yang saling tumpang tindih. Pada penggunaan 0,52 mol BZT, terlihat bahwa kedua puncaknya overlapping namun struktur kristalnya masih lebih dominan tetragonal daripada rhombohedral seperti 0,48BZT-BCT. Pada keadaan ini, perubahan fasa terlihat lebih jelas pada hasil sintesis dengan suhu sintering $950^{\circ} \mathrm{C}$ sehingga dapat disimpulkan bahwa daerah MPB terbaik berada di komposisi 0,5 mol. Hal ini sesuai dengan penelitian yang dilakukan oleh Mishra, et. al. (2012), MPB dari BZT-BCT berada di komposisi 0,5 mol.

Berdasarkan indikasi adanya perubahan fasa dari tetragonal menuju rhombohedral, maka parameter kisi dari kedua fasa tersebut.

Tabel 1. Hasil Perhitungan Parameter Kisi Rhombohedral dan Tetragonal

\begin{tabular}{|c|c|c|c|c|}
\hline \multirow{4}{*}{\begin{tabular}{l}
\multicolumn{2}{c}{ Komp } \\
osisi Mol \\
xBZT- \\
BCT
\end{tabular}} & \multirow{2}{*}{\multicolumn{2}{|c|}{$\begin{array}{l}\text { Rhomboh } \\
\text { edral }\end{array}$}} & \multirow{2}{*}{\multicolumn{2}{|c|}{ Tetragonal }} \\
\hline & & & & \\
\hline & $\mathrm{a}$ & $\alpha$ & $\mathrm{a}$ & $\mathrm{c}$ \\
\hline & 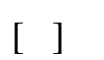 & {$\left[{ }^{\circ}\right]$} & 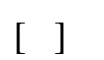 & [Ǻ] \\
\hline$=$ & 3 , & 9 & 3 , & 4 , \\
\hline $0,48 \mathrm{~mol}$ & 9945 & 0,01 & 9945 & 0185 \\
\hline$=$ & 3 , & 8 & 3, & 4 , \\
\hline 0,5 mol, & 9932 & 9,61 & 9934 & 0183 \\
\hline $\mathrm{x}=$ & 3, & 8 & 3, & 4 , \\
\hline 0,52 mol, & 9988 & 9,92 & 9975 & 0213 \\
\hline
\end{tabular}

Harga parameter kisi rhombohedral dan tetragonal ditunjukan pada Tabel 1. Pada masing-masing suhu sintering, nilai paramter kisi (a) dari rhombohedral dan tetragonal mengalami penurunan terkecuali pada komposisi $0,52 \mathrm{~mol}$ yang harga kisi a-nya meningkat. Hal ini diasumsikan terjadi karena penambahan BCT cukup banyak sehingga menyebabkan puncak dari pola difraksi bergeser ke kanan di mana posisi 20-nya semakin besar dan jarak antar bidang menjadi lebih kecil.

Hubungan antara parameter kisi a dan penggunaan komposisi mol BZT ditunjukan pada Gambar 4. 


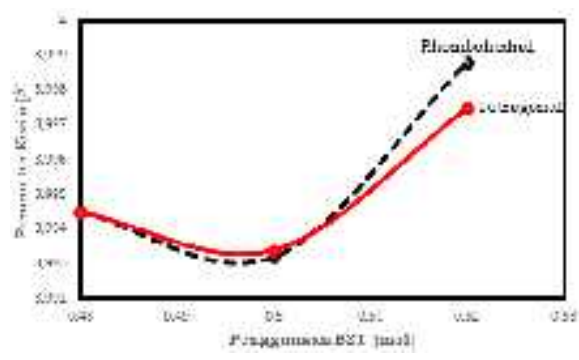

Gambar 4. Hubungan Harga a [Å]dari Rhombohedral dan Tetragonal terhadap $\mathrm{x}$ BZT-BCT pada suhu sintering $950^{\circ} \mathrm{C}$.

Parameter kisi a yang dihasilkan antara rhombohedral dan tetragonal terlihat berbeda antara rhombohedral dan tetragonal mulai dari penambahan 0,5 mol BCT. Terlihat pada. Hal ini Pada Gambar 4, perbedaan parameter kisi a semakin jelas terlihat antara struktur rhombohedral dan tetragonal. Hal ini diasumsikan bahwa pada 0,5BZT-BCT menjadi titik MPB.

\section{KESIMPULAN}

Berdasarkan hasil dari penelitian, diperoleh material xBZT-BCT disintesis dengan variasi komposisi $0,48, \quad 0,5$, dan $0,52 \mathrm{~mol}$ semenggunakan suhu sintering $850^{\circ} \mathrm{C}$. Struktur kristal yang dihasilkan oleh 0,48BZT-BCT suhu sintering $850^{\circ} \mathrm{C}$ adalah tetragonalrhombohedral. Daerah Morphotropic Phase Boundary-nya terdapat di komposisi $0,5 \mathrm{~mol}$.

\section{REFERENSI}

1. Yulianti, E., Triwahyuni, D., Ahda, S., \& Deswita. (2010). Sintesa dan Karakterisasi Bahan Piezoelektrik $\mathrm{Bi}_{0,5} \mathrm{Na}_{0,5} \mathrm{TiO}_{3}$ (BNT) dengan Metode Molten Salt. Jurnal Sains Materi Indonesia, 14, 13-17
2. Chandrakala, J. E., Praveen, P., Hazra, B. K., \& Das, D. (2015). Effect on Structural, Dielectric, Piezoelectric, and Ferroelectric Properties of Sol-gel Derived BZT-BCT Ceramics. Journal of Ceramics International.

3. Lin, Dunmin, Kwok, K. W., \& Chan, H. L. W. (2008). Effects of $\mathrm{MnO}_{2}$ on the Microsturcture and Electrical Properties of $0,94\left(\mathrm{~K}_{0,5} \mathrm{Na}_{0,5}\right) \mathrm{NbO}_{3}-0,06 \mathrm{Ba}\left(\mathrm{Zr}_{0,05} \mathrm{Ti}_{0.95}\right) \mathrm{O}_{3}$ Lead-Free Ceramics. Journal of Materials Chemistry and Physics, 109, 455-458.

4. Chen, Chao., Zhao, X. Y., Liu, Hong., Ge, W. W., Luo, H. S., \& Jiang, X.P. 2010. Crystal Growth and Electrical Properties of Lead-Free Piezoelectric Material $\left(\mathrm{Na}_{0,5} \mathrm{Bi}_{0,5}\right) \mathrm{TiO}_{3}-\mathrm{BaTiO}_{3}$. Key Engineering Materials, (421-422), 17-20.

5. Mishra, P., Sonia, \& Komar, P. (2012). Effect of Sintering Temperature on Dielectric, Piezoelectric, and Feroelectric Properties of BZT-BCT 50/50 Ceramics. Journal of Alloys and Compounds, 545: 210-215. 